Meta

Journal des traducteurs

Translators' Journal

\title{
The Subversive Scribe: Translating Manuel Puig
}

\section{Suzanne Jill Levine}

Volume 35, numéro 3, septembre 1990

La traduction dans le monde hispanolusophone

URI : https://id.erudit.org/iderudit/003505ar

DOI : https://doi.org/10.7202/003505ar

Aller au sommaire du numéro

Éditeur(s)

Les Presses de l'Université de Montréal

ISSN

0026-0452 (imprimé)

1492-1421 (numérique)

Découvrir la revue

Citer cet article

Levine, S. J. (1990). The Subversive Scribe: Translating Manuel Puig. Meta, 35(3), 632-641. https://doi.org/10.7202/003505ar d'utilisation que vous pouvez consulter en ligne.

https://apropos.erudit.org/fr/usagers/politique-dutilisation/ 


\section{THE SUBVERSIVE SCRIBE: TRANSLATING MANUEL PUIG}

SuZANne JiLl LeVIne

United States of America

Peut-être (...) le métier du traducteur est plus subtil, plus civilisé que celui d'écrivain : le traducteur vient évidemment après l'écrivain. La traduction est une étape plus avancée 1.

\section{TRANSLATION: A CREATIVE AND CRITICAL ACT}

Much debate has surrounded the translation of poetry. John Felstiner's Translating Neruda, for example, has made a pioneering contribution: his chronicle of the process of a verse translation demonstrates that while we may read a translation either ingenuously or conscious of its inadequacy, we are not aware of how translation is interpretation, functioning not only as a creative but as a critical act as well.

Translating literary prose has received less attention, no doubt because of the "notion that a novel is [...] a simpler structure than a poem and consequently easier to translate." 2 But the formal and linguistic complexity of twentieth-century fiction belies this notion. While the chief virtue of translators has traditionally been their invisibility scribes scribbling in the back room, serving the house of Literature - exploring the prose translator's role as creative literary critic may serve both texts and their readers well. For translation is only the most concrete form of the interpretive act performed by all readers, scholars and teachers of foreign literatures. Problematic and self-referential studies by prose translators may offer useful models of self-questioning for all interpreters.

\section{A POETICS OF TRANSLATION}

\section{A. "TRANSLATION" PRIVILEGES "ORIGINAL"}

In 1932 Jorge Luis Borges questioned, in an essay about the "Homeric Versions", the privileged status of the original versions of the Odyssey and the Iliad. Which interpretation of the original is the "original"? he asked - only a Greek from the tenth century B.C. could (maybe) tell us. Borges prefigures Foucault's challenge to the concept of authorship by inquiring: Who was (and what is) the author anyway? How can we determine intentionality? The only real difference between original and translation - Borges observes playfully - is that the translation's referent is a visible text against which the translation can be judged ${ }^{3}$.

In this meditation on translation we can find the seed of Borges" poetics of "reading as writing" which he articulates further in 1939 in his amusing parable "Pierre Menard, Author of Don Quixote." In this essay-story Cervantes' masterpiece is nothing but a tentative web of propositions which changes with each new historical act of reading. In Borges' poetics each successive interpretation (i.e. reading, rewriting, translating) of a text enriches and ensures the original's survival; moreover, every text enters into a dialogue with other texts, and with a context; texts are relationships which of necessity change in other contexts. In "Pierre Menard" we again see the foreshadowings of contemporary theory, in this case, intertextuality, reader response and reception theories. 
Borges has shown us - time and again - how literary texts already give us the theoretical models through which we may interpret them.

\section{B. WORK-IN-PROGRESS}

Borges has proposed, essentially, a more tentative view of the original, as one of many possible versions. James Joyce, collaborative translator of his own writing into Italian, was thinking along similar lines when he chose to call his originals "work-in progress" - which he continued to complete in the next stage, translation. In recreating passages of Finnegans Wake he elaborated - in this Romance language which he loved for its earthy musicality - on aspects of the original which became even more explicit in Italian. That is, he took advantage of Italian - and his relationship to Italian - to create a more slangy version, and different double, even triple puns 4 .

\section{TRANSLATION AS (SUB)VERSION}

Polyglot authors like Borges, Joyce, Pound, Beckett, and Nabokov have, of course, an authority to recreate, to "subvert" the original - particularly their own originals that most translators do not have. They offer a model, however, of what literary translation needs to be: creation. Having collaborated with writers such as Guillermo Cabrera Infante, Julio Cortázar, Carlos Fuentes and Manuel Puig, I have been able to observe the symbiotic relationship between translation and original composition.

Far from the traditional view of translators as servile, nameless scribes, I am suggesting that the literary translator can be considered a subversive scribe, and not only because translations are betrayals in the traditional "traduttore traditore" sense. An effective translation is often a "(sub)version", a version "underneath", implied in the original, which becomes explicit. This view corresponds perhaps to Walter Benjamin's mystical vision of the hidden harmony between distant languages which translation seeks to integrate. However, "subverting" particularly qualifies translating innovative writers like Severo Sarduy, Cabrera Infante and Manuel Puig since it continues the mode of their originals. They see their originals as translations of texts, traditions, realities, and as touching upon the gaps between language and meaning. The "author" has been dethroned in their writing, and as self-translators they are self-subverters.

\section{WRITERS/TRANSLATORS}

Cabrera Infante, Puig and Sarduy form a generational group which blossomed in the $1960 \mathrm{~s}$. Their work continues the avant-garde spirit of an earlier generation that included Borges, Cortázar and Lezama Lima but which breaks new ground particularly in exploring popular forms, in interpreting the modernist tradition with a more authentically Latin American, or better, Argentine/Cuban idiom.

Cabrera Infante, in his novel Tres tristes tigres (Three Trapped Tigers, 1971), is perhaps the first to make "Cuban" into a literary language, a language consisting of slang, wordplays and dislocutions, a Spanish enriched by a specific regional culture but also by many cultural and literary references. "The death of Trotsky" - a chapter of this vast fragmentary roman comique - consists of affectionate and savage parodies of Cuban writers. But Petronius' Satyricon (of which Cabrera Infante has called TTT a "failed translation"), Alice in Wonderland, Hollywood movies of the 40s and 50s also form part of the book's rich intertext. Manuel Puig's work can be considered in some ways more "pop", less "literary" in a traditional sense, reproducing and analyzing popular culture and the Argentine language within the sophisticated, stylized parodic structures of novels such as Betrayed by Rita Hayworth, and Kiss of the Spider Woman which was translated into a highly successful film. 
For brevity's sake I would like to focus my exposition on Puig's second novel Boquitas Pintadas (literally Little Painted Mouths or Lips), which became Heartbreak Tango in English. Our study of the process of translating this novel should help us see how translation functions as 1) a continuation of the creative process 2) a critical act which cannot and does not replace but rather complements the original, illuminating its strategies. Another issue - which transcends the purely literary - will also surface: that is, how do contextual constraints in the target culture influence the production of translations? What aspects of Spanish American texts are or aren't accessible to the American English reader? How do cultures/languages/literatures "refract" the texts produced by other cutures?

\section{BOQUITAS PINTADAS: PARODY OR NOSTALGIC REQUIEM?}

In Boquitas pintadas Puig continues to reconstruct the provincial word of his childhood in a small town on the Argentine pampas, which he had begun to do in his first novel, Betrayed by Rita Hayworth. But whereas the first book was explicitly autobiographical, a sort of Bildungsroman, Boquitas performs a socio-historical task. In presenting the lives of several interrelated characters from different social castes Puig attempts to understand, to analyze - empathetically - the demise of provincial bourgeois values in Argentina. Boquitas is in a way an elegy to this past, specifically the 30 s and 40 s, as the title, lyrics from an old song, suggests. But the book has mainly been described as a parody. It imitates the form of the soap opera or serial romance novel - appropriate to the melodramatic plot involving tragic love affairs and triangles - and an ironic, satirical effect is produced by Puig's mimicry of his characters'speech and his reproduction of outdated cultural artifacts.

Puig describes his "intentions" as follows:

When I wrote this novel, I was very interested in working with the language of the characters, because the way they spoke tells more about them than anything the author could explain. Most of the characters in the book are first generation Argentines, of Italian or Spanish parents, most of them peasants who hadn't been able to give their children any cultural heritage. Their traditions were peasants' or underdogs' traditions, but they wanted to suppress or forget them. Much the same happened with immigrants who came to the United States. This meant that the children of these people had no models of conduct at home, and, least of all, no models of speech. They therefore had to invent a language of their own, using the culture they had at hand. All they had were the popular songs of the era, the subtitles of films, and stories in women's magazines. These models were not the best, but they were the only ones available to the lower middle class in small pampas towns. Mainly they were unrealistic and romantic. The language was overblown and was meant to impress quickly. That's why the tango is so truculent: because it had to make an impression on an audience lacking any subtlety. The characters in my book, based on the people of that era, try to use the language of passion, and they even think they act passionately, too 5 .

What Puig sets out to demonstrate is the gap between the language his characters use to communicate, to fantasize about their lives, and the harsh, calculating reality of their existence. To produce this message for his reader, Puig had to recreate their language accurately so that the reader would recognize it, and establish an ironic distance between language and "reality" which the reader would perceive.

But Puig is quick to balk at the label "parody":

I think it is misleading. I' $m$ often embarrassed when someone says to me: "You mock the way poor people speak." That isn't my intention, and I' $m$ soory if it comes out that way. The point is that the ordinary speech of these people is already a parody. All I do is record their imitation. (p. 35) 
Puig is in a way both right and wrong. What he does is not mere "burlesque imitation" but, in the strictly formal sense, Boquitas is a parody, a work that imitates a conventional genre with the intention of imposing a critical difference, of producing a double message involving both praise (elegy) and criticism (mockery). Boquitas criticizes the false or exaggerated sentimentality of the tango, the glamorized images of Hollywood that reify his characters' behaviour, as well as the cliches and the alienated journalistic, bureaucratic forms of everyday communication.

But the praise is also there: Puig takes the refuse of popular culture - song lyrics, advertisements, sensationalist journalism - and recycles it; in this sense he is the artist as bricoleur, taking old material and creating something new, giving "used parts a second life" 6 . Bricoleur, in the Lévi-Strauss sense of the primitive tinkerer, but more precisely in Adorno's use of the term to qualify, for example, the composer Gustav Mahler who scandalized (in his time) bourgeois esthetics by taking folkloric material and using it in new ways that resisted "passive listening"7. The same applies to Puig: his books are entertainments, but for active readers. An apparent "praise" of popular forms involves also a criticism of "bourgeois esthetics". Puig's writing reevaluates "bad taste", provokes the reader to enjoy and not suppress it as "good taste" has done. Puig questions the category of "kitsch" since that word presupposes something shameful, a judgmental distance. Puig, as he claims, seeks the poetry in bad taste ${ }^{8}$.

Again, this empathetic reappraisal is also parody - which often transcends mockery and becomes sympathy. Or as Mikhail Bakhtin, the Russian post-formalist, put it: "another's word, having been at an earlier stage internally persuasive, mounts a resistance to [the ironic stylizing of parody] and frequently begins to sound with no parodic overtones at all." 9 Through the process of reading Boquitas pintadas we, the readers, grow to empathize with the characters despite their corny cliches, or maybe even because of the way they speak. They are all Don Quixotes, aspiring to what they are not, to what they cannot have. The borrowed words they unconsciously "parody" are ultimately "authentic" - or at least the only language to which they have access. As readers, we are no longer laughing at their absurdity but rather crying with their predicament, which is - at a more sophisticated level perhaps - our own.

\section{THE TANGO: AUTHENTICALLY ARGENTINIAN OR MENDACIOUS MYTH?}

An awareness of a book's intended effect on its original reader is obviously necessary in order for us to understand the difficulties of repeating that effect. The author's intentions - overdetermined by his/ her own context - may or may not be verifiable, or even relevant, but the translator - like all interpreters - has to decide, within a given context, what functions / he is trying to fulfill. In Boquitas, how to recreate in English the parodical effect that spoken Argentine has upon its intended reader? It's hard to imagine how I would have translated Boquitas without Puig's collaboration, precisely because another and yet a very Argentinian book had to be written. Again, for brevity's sake, I would like to examine here the main impasse - which involves the translation of the title - that is, how to reproduce in translation the "flavor", the function of the tango lyrics in the original version?

While, as in his novel Betrayed by Rita Hayworth, imported films (or domestic films modeled after the Hollywood imports) continue to be an influential medium upon the characters of Boquitas (at one point a female character fantasizes that her greatest desire is for Robert Taylor to enter her bedroom), in Boquitas the tango, an "authentic indigenous" form - and a dominant manifestation of popular Argentine culture during the $30 \mathrm{~s}$ and $40 \mathrm{~s}$ - appropriately takes the foreground. 
As one Argentine critic remarked, "the artificiality of those films, the way in which they make the viewer participate in their conventions, is similar to the structure of the tangos by Alfred Le Pera, tangos that we cannot help but imagine being sung by Carlos Gardel, the legendary tango singer and star of musical pictures, who interpreted the tragic tango lyrics with a sarcastic and oblique voice ${ }^{10}$."

In the original Boquitas quotations of tango lyrics appear as epigraphs at the head of every episode, a phrase or a few words that immediately touch the Argentine reader by invoking a well-known melody, and evoking thus a mood, or a theme (seduction and abandonment, betrayal, the death of a lover). Here is a list of the first four epigraphs, accompanied by their "translations":

Boquitas pintadas

I. "Era [...] para mi la vida entera ..." (She was my whole life)

II. "Charlemos, la tarde es triste ..."

(Let's talk, it's a sad afternoon)

III. "Deliciosas criaturas perfumadas, quiero el beso de sus boquitas pintadas ..."

(Delicious perfumed creatures, I want a kiss from your painted lips ...)

IV. "... sus ojos azules muy grandes se abrieron..." (her eyes of blue did open wide)

Alfred Le Pera

\section{Heartbreak Tango}

The shadows on the dance floor, this tango brings sad memories to mind, let us dance and think no more while my satin dress like a tear shines.

(H. Manzi's tango, "His voice")

As long as you can smile, success can be yours.

(radio commercial for toothpaste,

Buenos Aires 1947)

She fought with the fury of

a tigress for her man!

He treated her rough - and

she loved it!

(ad for Red Dust, starring

Jean Harlow, Clark Gable)

My obsession, heartbreak tango, plunged my soul to deepest sin as the music of that tango set my poor heart all a-spin.

(Roldan's "Blame That Tango")

These familiar quotations relate as "imaginative stimuli" or as models to the characters, plot and/or narrative form of each chapter. The Spanish-speaking but particularly the Argentine reader - whose feelings have been awakened by a musical memory immediately captures the intonation of these words, what is implied between the said and the unsaid. Their exaggerated "bad taste" and the popular singer Gardel's sarcastic interpretations add a self-reflexive dimension, a distancing effect heightened by the novel's historicity. Their function as both nostalgic and ironic counterpoint is "heard" by the Argentine reader, but for the American reader, for example, a literal translation of poetic cliches like "She was my whole life" rings hollow. It could be a line from a popular song, but the specific tone, the contact between the speaker and the listener, is lost.

The tango "means" something else anyway outside of the "River Plate" (as the British nicknamed the region); for Europeans and North Americans, Latin American dance music has always had a stylized Latin connotation, whereas in Argentina the tango is as homespun as blues and jazz are in the United States. But it would have been absurd to substitute Billy Holliday's singing for Libertad Lamarque's or Cole Porter's lyrics for 
Alfred Le Pera's. The original cultural referent would have been completely erased by such a drastic transposition. And American popular music - according to Puig's representations of Argentina of the 30s and 40s - did not invade the popular consciousness and media as significantly as the Hollywood cinema and consumeroriented advertising.

We had to come up with effective equivalents or substitutions. The solution that we finally came up with was to translate some tango lyrics that were essential to the plot (I'll soon explain), but to substitute at least half of the epigraph quotations with either tag lines from Hollywood films or Argentine radio commercials (originally based, most probably, on Madison Avenue inventions) [please consult the list above]. That is, artifacts relevant to the original context but which rang a funny, familiar, exaggerated bell for American readers. The "Red Dust" tagline, for example, glamourizes sexism, machismo and feminine submissiveness: an appropriate epigraph to Episode III which introduces the main male lead, Juan Carlos, with whom women are always falling fatally in love. In "real life" we discover he's an insecure lout, and Mabel, his favorite girlfriend, also introduced in this episode, accepts an archetypal submissive role in appearance but is - in reality - a very tough and calculating woman.

These substitutions added a new dimension of interpretation, or more precisely, they emphasized certain elements in the text which had been more implied than explicit. For example, the highlighted advertisements (see, for example, the epigraph to episode II) underscore Puig's implicit comment on the commercialization of culture, as well as his intent - in writing the books he writes - to show how the popular media has broken down the traditional distinction between consumerism and art. And by placing Hollywood movies on an equal plane with Argentine tangos (the "Red Dust" quotation is one of several movie epigraphs), it would appear that the translation suggests perhaps an equivalence between the cultural role of Hollywood, USA productions - produced in an "atmosphere of un-reality for a passive audience [...], [and] the role of Argentine music rooted in a popular participation in the present." 11 Making this equivalent could be dangerous, and subversive.

That is, if Puig's works are commenting - among other things - on the alienating effects of North American cultural imperialism, isn't this criticism mitigated in translation by the foregrounding of U.S. culture at the expense of "indigenous" Latin American cultural phenomena?

I would reply both yes and no to this question. Yes, the target culture does to a certain extent censor the ideology of the source text; an ideological subversion does occur by the mere fact of rewriting - appropriating - these books in American English. Translation is a form of conquest, Pound, in Nietzschean spirit, has shown us. But the other side of the coin is, if the reader cannot recognize the book's parodical effect, its ideology is suppressed even more radically.

What is more to the point here is that both original and translation have placed both the sentimental tango and the glamorous Hollywood movies in a critical perspective. That is, we first have to understand - as the Argentine reader does - what Puig is saying about the tango and its supposed "authenticity," or more specifically, the middle class' relationship to a popular form which arose out of the "lower depths".

Like jazz, the tango was accepted by its middle class milieu only after it had been canonized in Paris, the fashion center and cultural capital of the world (in the 19th - and a good part of the 20th - century). But in the process of passing from the "barrio Sur" and the brothels, the tango had undergone a "translation". What had been originally considered obscene (couples bumping and grinding in a tight embrace) had become - as Borges put it - "melancholy ... languid ... nostalgic."12 
While Puig articulates his characters' values in authentic Argentine terms, he is showing - through ironic juxtapositions - how these "original" terms are, in a way, false ones, translations, particularly for the "upwardly mobile" middle class. As he says: "the characters in my book [...] try to use language of passion, and they even think they act passionately, too." Only the working class characters - in Puig's view — wholeheartedly adhere to the tango's melodrama. It was precisely the tangos echoing in the thoughts of the main working class female character, the maidservant Fanny, which somehow had to be "faithfully" translated ${ }^{13}$. In episode XI, Fanny is listening to tangos on the radio as she scrubs the floors in the house of middle class Mabel; as she hums the tangos, she reflects on the stages of her love affair with Pancho which the different tangos evoke.

The artificiality of the supposedly authentic gives us a clue to the motivation behind the apparently lighthearted title, Boquitas pintadas: these words are not tango lyrics but, treasonously, from a fox trot titled "Blondes of New York". "Rubias de New York" was a very popular song in the 30 s, sung of course by the legendary Gardel in an Argentine movie called the Tango on Broadway — a movie which, for Argentines, glamorized the tango and their star in a Hollywood context. One could almost say that the fox trot lyrics "Boquitas pintadas" emblematize the tango's displacement.

But what are the roots of Argentine culture? The Mexican Carlos Fuentes quoted the following boutade in an essay on the new Spanish American novel (1969): "The Mexicans descended from the Aztecs, the Peruvians from the Incas, and the Argentinians from the boat". A burlesque reduction of course, but such indeed was the cradle of the quintessential Gardel - the illegitimate son of a Frenchwoman from Toulouse. Gardel's fox trot on Broadway can be read not only as the tango's betrayal but as a confirmation of Argentina's imported origins.

\section{EXPANDING THE CONTEXT}

Hence, the translation of Boquitas pintadas, though foregrounding the movies more than the original, continues the critical act begun in the original: exposing the tango's lies by juxtaposing them with the false values of a foreign popular (or mass media) culture, by reproducing these diverse artifacts in an "analytic" ironic context. Again, to understand how Boquitas became Heartbreak Tango the reader has to be conscious of the necessary transformations a text undergoes in a different context, how inter and contextual relationship change. The translator-as-critic has to expand the context, and take into consideration 1) the reception of the work in other cultures, and his/her own function as mediator between past and present, between one culture and another; and 2) the relationship of the work to the author's entire opus, in Puig's case, the significance of Hollywood mythology throughout his writing.

Regarding our first consideration - the reception of the work in another culture as an interpreter of Latin American literature for North American readers, I had to be cognizant of the fact that the "collective memory" shared by Puig's readers outside of Argentina is not the tango but the mythology of Hollywood. Even the more widely distributed edition published in Spain underwent changes to make the book accessible in the way it had been for Argentine readers. For certain epigraphs complete stanzas (see above list) from the tangos were quoted - the one-liners wouldn't have been familiar enough. As in the American English edition, some of Le Pera's tangos were substituted by Homero Manzi's which, as Puig noted, told stories with more concrete imagery. An example of Manzi's are the translated lyrics in the epigraph to episode I - more vivid to an American reader than a literal translation of the original tango quotation. But even in the Spanish (Spain) edition the lyrics could not work as musically, i.e. subliminally, implicitly signifying, as in the original; but they had to, at least, as they do in the English translation, serve an explicit thematic function. 
Translation, though it necessarily practices the rift between sign and meaning, finally seeks to (re)unite signs with meanings. Even though the translated epigraphs strayed - semantically and formally - away from the originals, they reinstated meaning in a broader sense, transmitting their function, the semantic and/or formal relationship between the head (epigraph) and the body of the episode.

Now to another consideration: the author's original and its relationship to his textual universe. In a discussion of the status of self-translation in the works of Samuel Beckett, it has been observed that the original is no longer necessarily the first work but rather the "sum total of textual material constituted by all the early drafts." 14 Although Beckett is a unique case, this observation applies to some extent to writers like Puig and Cabrera Infante who collaborate extensively on the translations of their work, and who even write in English.

Puig's "found objects" - taken from popular mass culture - cover a broad range of textual artifacts, some of which appear quoted in his originals. The fact that in the epigraph to episode I, one tango can replace another, reminds us not so much of translation's inadequacy as of the provisional, makeshift nature of the original. Or as Borges tentatively concluded in his essay on the versions of Homer, "the concept of a definitive text pertains either to fatigue or to religion." The interchangeability of certain textual artifacts (tango for tango, movie tagline for tango) indicates that what matters here is not the unicity, the monolithic value of a quoted text but rather the relationship between texts, a relationship that changes according to the milieu of reception. Just as many tangos (and other texts) are not but could have been potentially incorporated into the original Boquitas.

\section{REMOTE BUT INTELLIGIBLE}

Which goes back to what was said earlier about the novelist as a bricoleur: he doesn't invent but rather finds words which resonate in the ear of the reader. In order for the translation to be a dialogue between writer and reader as it is in the original, the translator too must become a tinkerer. Again, the translator concretizes the historical act that all writers/readers/interpreters perform: s/he mediates between past and present.

To continue the dialogue between Puig's novel and its readers, we - as collaborators - had to recreate the context. If the translated title was to somehow "fulfill" the original title's function it had to register in the ear of its reader, to suggest nostalgia for a past era, to satirize sentimentality in popular culture, and to anchor the book in its Argentine, or at least Latin American frame of reference. As is often the case with titles - originals and translations - Heartbreak Tango didn't come to us until the last minute, when I had finished the translation. As mentioned earlier, necessity - that of translating lyrics essential to the plot - was the mother of our invention:

Maldito Tango

“...en un taller feliz yo trabajaba, nunca sentí deseos de bailar..."

"...hasta que un joven que a mi me enamoraba llevome un día con el para tanguear..."

\section{Blame That Tango}

I was happy in the sweatshop, felt no need to dance at all...

till the day a gallant wooer came to take me to the hall... 
"fue mi obsesión el tango de aquel día,

en que mi alma con ansias se rindió, pues al bailar sentí en el corazón que una dulce ilusión nació..."

"...la culpa fue de aquel maldito tango, que mi galán enseñome a bailar, y que despues hundiéndome en el fango, me dio a entender que me iba a abandonar..."
My obsession, heartbreak tango plunged my soul to deepest sin as the music of that tango set my poor heart all a-spin

I will aways blame that tango and the wooer with his wiles once he'd made my heart break all he told me was good-by

Heartbreak Tango are lyrics from our translation of Maldito Tango - the tango cited in the original episode XI which brings to Fanny's mind what happened between herself and the bricklayer Pancho who seduced and abandoned her; as you can see, seduction and abandonment is the theme of this typically bitter tango. The translation was a bricoleur's find because, simply, it worked. That is, though the unique tango rhythm is lost - in which the stress of each line falls characteristically at the end, a dark downward motion - at least our translation parodied the mechanical rhyming, and told its story in comically heavy-handed language: (READ stanza: mi obsesión...) Since the "Cursed Tango" was to blame for this tale of seduction, I translated the title of it (literally Damn Tango) as Blame That Tango, a Hollywood resonance, inspired in Put the Blame on Mame; but also evoking (and this choice as it often does, occured purely intuitively) a syncopated Latin-like rhythm, as in Hold That Tiger. Our associations here were not random but, on the contrary, relevant to Puig's world: Put the Blame on Mame invokes the image of that treasonous femme fatale icon of Puig's first novel, Rita Hayworth, who sings and dances this number in Gilda, a 40s film noir (which Puig decided to quote in his following novel, The Buenos Aires Affair).

This translated song helped us to reconstruct an appropriate context: in terms of theme and mood it characterized the era, the very "Latin" frame of reference, and a principal theme of the book - disillusionment. We decided to quote different stanzas from it in two epigraphs (IV and IX) to prepare the reader for its appearance in episode XI. It would become an (almost) familiar motif — like "boquitas pintadas" — which would epitomize the book for the reader. Thus - seeking symmetry - we chose lyrics from Blame That Tango, that is, the words Heartbreak Tango ("Heartbreak" resonates with indigenous U.S. associations, country and western, Elvis Presley's "Heartbreak Hotel" wrong period but a similar corny effect) for the new book's title.

The creative aspects of this tinkering are (I hope) self-evident but it is perhaps necessary to underscore the critical implications. We chose to foreground - to be a critic is to choose, to distinguish - a song in the book which, though it had been quoted only once, in our interpretation was a potential key, an internally persuasive text. Again, what was implied became explicit in translation.

Donald Keene, a distinguished translator of Japanese literature, once observed that when translating obscure, or culturally-bound allusions, the translator should produce an effect that was remote but intelligible15. Heartbreak Tango, with "tango" in the title, and the particular details of everyday Argentine life in every page of the text, marks its cultural difference, remaining a "remote" book despite the fact that Puig's humor is made "intelligible".

Perhaps more important, Heartbreak Tango performs, like Boquitas, a critical task, exhibiting the false and real values of popular culture in Argentina - by reproducing these textual ruins in an "analytic" context. The translation responds not only to the author's context - which includes the cinematic subtext that unifies all of Puig's novels - but, most urgently, to its potential reader(s). 


\section{NOTES}

1. CHARBONNIER, G. (1967): Entretiens avec Jorge Luis Borges, Paris, Gallimard, p. 14

2. BASNETT-MCGUIRE, S. (1980): Translation Studies, London \& New York, Methuen, p. 109.

3. See "Las versiones homéricas", Discusión, Buenos Aires, Emece Editores, p. 112.

4. See RISSET, Jacqueline (1984): "Joyce Translates Joyce", Comparative Literature: An Annual Journal, ed. E.S. Shaffer, New York \& London, Cambridge University Press, pp. 6-11.

5. LEVINE, S.J. (1974): "Author and Translator: An Interview with Manuel Puig", Translation, New York, Colombia University Press, p. 34

6. ADORNO, T. (1980): "The Fetish Character in Music and Regression of Listening", The Essential Frankfurt Reader, New York, The Continuum Publishing Co., p. 298.

7. Cf. LEVI-STRAUSS (1966): The Savage Mind, the University of Chicago Press, and the above-cited Adorno.

8. TORRES FIERRO, D. (1986): "Manuel Puig", Memoria Plural: Entrevistas a escritores latinoamericanos, Buenos Aires, Editorial Sudamericana, p. 208.

9. BAHKTIN, M. (1981): "Discourse in the Novel", The Dialogical Imagination: Four Essays, tr. Caryl Emerson and Michael Holquist, ed. Michael Holquist, Austin, University of Texas Press, p. 348.

10. BORINSKY, A. (1975): "Castration: Artifices: Notes on the Writing of Manuel Puig", The Georgia Review, vol. XXIX, no 1 , Spring, p. 106

11. WEISS, J. (1974): "Dynamic Correlations in Heartbreak Tango", Latin American Literary Review, Pittsburgh, Fall-Winter, p. 139.

12. REBORA. H. ed. (1982): Granada/Tango, Granada, La tertulia, p. 74

13. "Fanny" is my translation of the character's original nickname, La Raba, literally "chicken tail", identifying an "outstanding" part of her anatomy.

14. FITCH, B.T. (1985): "The Statues of Self-Translation", Texte 4, Toronto, p. 118

15. See "The Translation of Japanese Culture", in Landscapes \& Portraits: Appreciations of Japanese Culture, Tokyo \& Palo Alto, Kodansha International Ltd., pp. 322-329. 